AFRICA

Economic Growth and Measurement Reconsidered in Botswana, Kenya, Tanzania, and Zambia, 1965-1995. By Morten Jerven. Oxford: Oxford University Press, 2014. Pp. vi, 215. $\$ 90.00$.

doi: $10.1017 / \mathrm{S} 0022050716001133$

The first substantive chapter, "African Economic Growth Reconsidered," is a critique of the cross-country regressions of the 1990s that sought explanations for Africa's growth performance. Jerven makes the point that analyses based on long-run averages miss that African growth performance only worsened from the 1970s on. In addition, ignoring this timing makes African policy choices appear unduly important relative to exogenous shocks, complicates stories in which time-invariant variables such as ethnic divisions matter, and serves the case for structural adjustment. Jerven is particularly critical of the narratives in Benno J. Ndulu et al. (eds.) The Political Economy of Economic Growth in Africa, 1960-2000. Cambridge: Cambridge University Press, 2009.

Jerven's criticisms of cross-country regressions are correct and well-known. Many papers on African growth published since the 1990s have attempted to address these issues. Better panel approaches base inference not off questions such as "did Botswana outperform Zambia over the whole period" but rather "was Botswana's performance relative to its long-run average this sub-period better than Zambia's performance relative to its own long-run average this sub-period?" Some papers have already validated Jerven's point that many sources of African growth are external (e.g., S. Barrios et al. "Trends in Rainfall and Economic Growth in Africa: A Neglected Cause of the African Growth Tragedy." The Review of Economics and Statistics 92, no. 2 [2010]: 350-66 on rainfall). Others use these external shocks to answer other questions (e.g., M. Brückner and A. Ciccone. "International Commodity Prices, Growth and the Outbreak of Civil War in Sub-Saharan Africa." The Economic Journal 120, no. 544 [2010]: 519-34 uses global commodity prices).

Jerven's point would be stronger, however, if he demonstrated that the conclusions drawn from the cross-sectional literature of the 1990s no longer hold using such methods. Some recent work using the panel dimension of the data has indeed validated the unimportance of variables that appeared to matter in the cross-section, as with R. Rajan and A. Subramanian. "Aid and Growth: What Does the Cross-Country Evidence Really Show?" The Review of Economics and Statistics 90, no. 4 [2008]: 643-65 on foreign aid. Other recent work has, however, supported findings from these older papers. One example is A. Estevadeordal and A. Taylor. "Is the Washington Consensus Dead? Growth, Openness, and the Great Liberalization, 1970s-2000s." Review of Economics and Statistics 95, no. 5 [2013]: 1669-90 on tariffs. Without such re-analysis of the publicly-available data, the book relies on what is probable, not what is shown.

Where one still sees cross-sectional analyses today is in the study of potential determinants of growth that do not change over time. Jerven rightly argues that the effects of these variables may only matter at certain times, or may matter only if they are made conditional on other variables. N. Nunn. "The Long-term Effects of Africa's Slave Trades." The Quarterly Journal of Economics 123, no. 1 [2008]: 139-76, for example, shows that the gap between high-slave-export and low-slave-export countries has only opened recently. 
The chapter entitled "Measuring African Economic Growth" discusses the lack of real data used by African statistical agencies, and shows the guesswork that goes into estimates of prices, of population, of non-market production, and of other components of economic activity. The result "is not as accurate as economists sometimes assume." In the third substantive chapter, "Measurement in Botswana, Kenya, Tanzania and Zambia, 1965-95," he shows how wide these errors can be; correlations between growth rates from different sources such as the World Development Indicators or the Penn World Tables are low, and the discrepancy between the low and high estimates for a single country-year can be very large.

That African data is unreliable is well known. See, for example, J. Henderson et al. "Measuring Economic Growth from Outer Space." The American Economic Review 102, no. 2 [2012]: 994-1028. Though Jerven criticises "economists" for their use of African data, he appears to do this mostly by looking at older work and work not published in peer-reviewed journals. This is driven, in part, by his focus on country cases rather than broader studies of economic growth. The only citations to articles in economics journals from the past decade I could find were (a) two articles in economic history journals and (b) a theoretical piece by Nathan Nunn. Jerven's critique of economists would had been stronger had he engaged with recent work by economists in peer-reviewed journals.

Jerven is concerned with the "reliability" of African economic data. More useful would be a concern with systematic errors that might induce spurious correlations between growth estimates and the possible causes of growth. For example: if rainfall were used to construct estimates of agricultural output, then this would increase the estimated effect of rainfall on growth.

Similarly, he could show that conclusions reached with one measure of economic growth no longer hold using alternative series. Does the correlation of slave exports with Maddison GDP estimates weaken when using World Bank estimates? "Narrow" and "broad" replications have grown common as the convention of making replication materials available online has spread.

The remaining six chapters consider growth mismeasurement in Botswana, Kenya, Tanzania, and Zambia. The chapter on Botswana outlines the shaky foundations of each component of the official GDP estimates, particularly before the 1980s. Jerven identifies several likely periods of "statistical growth" - that is, growth arising from the addition of previously unmeasured parts of the economy. He re-considers the mainstream narrative of Botswana's economic success, for example, G. Maipose and T. Matsheka's "The Indigenous Developmental State and Growth in Botswana" in Benno J. Ndulu et al. (eds.) The Political Economy of Economic Growth in Africa, 1960-2000. Cambridge: Cambridge University Press, 2009: 511-46. This view holds that Botswana succeeded by failing to adopt bad policies. Jerven suggests that that Botswana simply did not have the opportunity; diamond selling was handled by De Beers from the start. Democracy in the country has not threatened the ruling party, and import-substitution was pursued, but later than in other African nations.

The other chapters follow a similar pattern. Jerven demonstrates weaknesses in the data construction, provides a narrative of economic growth from the official sources, and argues that policy-centric narratives in "The Political Economy of Economic Growth in Africa" do not have sufficient empirical support. In Kenya, the standard account of rapid growth under Kenyatta and slow growth under Moi requires the pre-Moi slowdown and 
the growth of the late 1980s to be ignored. In Tanzania, the policy regime said to be responsible for slow growth was a response to external shocks. In Zambia, much is to be explained by real copper prices, and little by policy.

In sum, Jerven shows African GDP data is unreliable, and argues the importance of policy has been overstated. I would have preferred to see the latter claim substantiated with re-analysis of the data.

JAMES FENSKE, University of Oxford

\section{SOUTH AMERICA}

Inglorious Revolution: Political Institutions, Sovereign Debt, and Financial Underdevelopment in Imperial Brazil. By William R. Summerhill. Yale University Press, 2015. Pp. xiii, 342. $\$ 85.00$, cloth.

doi: $10.1017 / \mathrm{S} 0022050716000887$

Inglorious Revolution contributes importantly to economic history from several perspectives. It is a very well-researched, readable, and comprehensive financial history of Brazil during the nineteenth century, and an interesting case study in the linkages between public and private sector finance. The book argues two related hypotheses: (1) the Brazilian state was a successful sovereign borrower in foreign (London) and domestic markets through the nineteenth century; and (2) success with sovereign debt did not translate into success in private sector financial markets. William Summerhill contextualizes this argument within the influential work of Douglass North and Barry Weingast ("Constitutions and Commitment: The Evolution of Institutions Governing Public Choice in Seventeenth-Century England." this Journal 49 [1989]: 803-32), which postulates that institutions protecting sovereign debt obligations are also central to the development of private financial markets. Inglorious Revolution finds that success for a sovereign borrower, defined as the Brazilian state not having completely defaulted on its debt throughout the Imperial regime (1824-1889), is not a sufficient condition for private-sector success. The comparative perspectives of the book are with "successful" (mostly Anglo-American) financial systems and with the abject failures of sovereign debt among the newly independent Spanish American colonies.

Strong governance institutions, embedded in the Constitution, established the foundations necessary for success as a sovereign borrower. These institutions denied the executive branch the unilateral ability to default on either domestic or foreign debt. Summerhill argues that legislators were also purchasers of domestic bonds, and therefore, protected their investment in Imperial debt with constitutional constraints. When turning attention to structuring the institutions of private financial markets, policymaking legislators did not enable company formation and capital accumulation. These arguments unfold in successive chapters that explain his theoretical models, and explore each of the major financial markets germane to the story: foreign and then domestic sovereign debt markets, corporate capital accumulation and banking. The concluding chapter proposes that the end of Imperial governance and financial reform (resulting in sovereign and private market crises) occurred together. Appendices explicate the 